\title{
Phytochemical Study and Antioxidative Property of Ethanolic Extract from Termitomyces clypeatus
}

\author{
Payel Mitra ${ }^{1,2}$, Narayan Chandra Mandal ${ }^{2}$, Anirban Roy ${ }^{3,}$ Krishnendu Acharya ${ }^{1 *}$ \\ ${ }^{1}$ Molecular and Applied Mycology and Plant Pathology Laboratory, Department of Botany, University of Calcutta, Kolkata, West Bengal - 700019, India. \\ ${ }^{2}$ Mycology and Plant Pathology Laboratory, Department of Botany, Visva-Bharati, Santiniketan- 731235, India. ${ }^{3}$ West Bengal Biodiversity Board, Poura \\ Bhawan, Salt Lake City, Sector III, Kolkata- 700016, India.
}

\begin{tabular}{l} 
ARTICLE INFO \\
\hline Article history: \\
Received on: $11 / 03 / 2016$ \\
Revised on: 22/04/2016 \\
Accepted on: 01/06/2016 \\
Available online: $28 / 07 / 2016$ \\
\hline Key words: \\
Antioxidant, free radicals, \\
HPLC, phytochemicals.
\end{tabular}

\begin{abstract}
The present study documents the phytochemical screening and antioxidant properties of ethanolic extract of Termitomyces clypeatus. Phytochemical constituents like phenols, flavonoids and ascorbic acid were much higher than $\beta$ carotene and lycopene. The analysis of the phenolic compounds performed by HPLC, revealed the presence of pyrogallol $(0.223 \mu \mathrm{g} / \mathrm{mg})$ and cinnamic acid $(0.095 \mu \mathrm{g} / \mathrm{mg})$. Antioxidant activity was evaluated through superoxide radical scavenging assay, DPPH radical scavenging assay, chelating ability, reducing power and total antioxidant capacity determining assays. Their $\mathrm{EC}_{50}$ values ranged from $0.21 \mu \mathrm{g} / \mathrm{ml}$ to $3.22 \mathrm{mg} / \mathrm{ml}$. Result implies that $T$. clypeatus can not only serve as a food supplement but also be used as treatment for various oxidative stress related diseases.
\end{abstract}

\section{INTRODUCTION}

Free radicals and degenerative diseases are associated with aging and include cancer, cardiovascular disease, immunesystem decline, brain dysfunction and cataracts (Ames et al., 1993; Khatua et al., 2013). As oxidative damage to DNA, proteins and other macromolecules accumulates with age; leads to aging (Fraga et al., 1990; Harman, 1981). Free radicals such as superoxide, hydrogen peroxide and hydroxyl radicals, which are mutagens produced by radiation, are also by-products of normal metabolism (Sies, 1986; Wagner et al., 1992). Our own immune system at times is unable to combat these reactive oxygen species (ROS). Hence, the need for antioxidants creeps in. As carcinogenic properties have been reported for some synthetic antioxidants, research in the last three decades on the potential use of natural antioxidants from plants and mushrooms have received much importance. Extracts from mushroom have received attention based on their safety and records of health promotion. It has been also established that they are less toxic. They may act directly as antioxidant or prevent underlying

\footnotetext{
* Corresponding Author

Email: krish_paper@yahoo.com
}

oxidative stress related pathological conditions such as cancer (Chatterjee et al., 2014), heart ailments (Biswas et al., 2011), diabetes (Biswas and Acharya, 2013), inflammation (Biswas et al., 2010), gastric ulcer (Chatterjee et al., 2013), hepatic damage (Acharya et al., 2012; Chatterjee et al., 2012), microbial pathogens (Rai et al., 2013), parasitic organisms (Mallick et al., 2014, Mallick et al., 2015) etc. Termitomyces clypeatus R. Heim commonly known as "bali chatu" by the local people of lateritic zone of West Bengal has been traditionally used as food for their flavour, texture and delicacy. Recently a water soluble pure polysaccharide with average molecular weight of $\sim 1.98 \times 10^{5} \mathrm{Da}$ was isolated from $T$. clypeatus having strong antioxidative properties (Pattanayak et al., 2015). As far as our literature survey says the antioxidant activity of ethanolic rich fraction of this mushroom from West Bengal has not yet been published. In this scenario the present investigation was done. We have examined the antioxidant activity of ethanolic fraction of $T$. clypeatus employing various in vitro assay models such as superoxide radical scavenging activity, DPPH radical scavenging activity, chelating of ferrous ion, reducing ability and total antioxidant capacity along with a phytochemical screening for determining the usefulness of this mushroom as a functional food. 


\section{MATERIALS AND METHODS}

\section{Collection, Preparation of sample and authentication}

The mushroom $T$. clypeatus was collected from West Midnapore district of West Bengal. With proper scientific measures they were brought to the laboratory and cleaned well. Identification was done following standard literature (Karun and Sridhar, 2013). The voucher specimen has been deposited in the Calcutta University Herbarium (CUH) with the accession number CUH AM 351.

Ethanolic fraction was extracted according to the method of Dasgupta et al. (2013). Dried and powdered basidiocarps of $T$. clypeatus were extracted with ethanol at $25^{\circ} \mathrm{C}$ for 2 days and filtered. After filtration, the residue was re-extracted with ethanol. After filtration the filtrate was concentrated under reduced pressure in a rotary evaporator. Now, this concentrated ethanolic extract of $T$. clypeatus was stored at $4^{\circ} \mathrm{C}$. The percentage yield extracts were calculated based on dry weight as:

$$
\text { Yield }(\%)=\left(\mathrm{W}_{1} \times 100\right) / \mathrm{W}_{2}
$$

Where $\mathrm{W}_{1}=$ weight of extract after solvent evaporation; $\mathrm{W}_{2}=$ Weight of the minced mushroom.

\section{Phytochemical screening}

The content of total phenolic compounds in the ethanolic extract of $T$. clypeatus was estimated using Folin-Ciocalteu reagent (Singleton and Rossi 1965). Gallic acid (10-40 $\mu \mathrm{g}$ ) was used as a standard and expressed as $\mu \mathrm{g} / \mathrm{gallic}$ acid equivalents/g of extract. Aluminium nitrate and potassium acetate were required to determine total flavonoid content (Park et al., 1997) and quercetin (5-20 $\mu \mathrm{g}$ ) was used as a standard and presented as $\mu \mathrm{g}$ of quercetin equivalents/ $g$ of extract. Quantification of ascorbic acid was done by titration against 2, 6-dichlorophenol indophenol dye using oxalic acid (Rekha et al., 2012). Beta-carotene and lycopene were estimated by measuring absorbance at 453, 505 and $663 \mathrm{~nm}$ (Nagata and Yamashita, 1992).

\section{Detection of Phenols and flavonoids by HPLC}

The phenolic profile of the extract was determined using eleven standards of Sigma Aldrich (MO, USA) like gallic acid, chlorogenic acid, vanillic acid, p-coumaric acid, ferulic acid, myricetin, salicylic acid, quercetin, cinnamic acid, pyrogallol and kaempferol. For quantitative analysis, a calibration curve (10-50 $\mu \mathrm{g} / \mathrm{ml}$ ) for each phenolic standard was constructed.

\section{Antioxidant Activity}

Following methods of Martinez et al. (2001) superoxide radical scavenging activity of the ethanolic extract of $T$. clypeatus (0.2 $\mathrm{mg} / \mathrm{ml}-0.6 \mathrm{mg} / \mathrm{ml})$ was determined. BHA was used as a positive control. DPPH radical scavenging activity was determined for concentrations $2.0 \mathrm{mg} / \mathrm{ml}$ to $3.0 \mathrm{mg} / \mathrm{ml}$ following the protocol of Shimada et al. (1992). Various concentrations $(0.1-0.3 \mathrm{mg} / \mathrm{ml})$ of the extract were checked if they can chelate ferrous ion, based on methods stated by Dinis et al. (1994). Reducing power of the extract was determined spectrophotometrically at $700 \mathrm{~nm}$ as per methods of Oyaizu (1986) using ascorbic acid as standard verses different concentrations (1.0-2.0 $\mathrm{mg} / \mathrm{ml})$. Total antioxidant capacity assay was also carried out as described by Prieto et al. (1999) with little modification (Mitra et al., 2014). The activity was expressed as the number of equivalents of ascorbic acid (AAE). $\mathrm{EC}_{50}$ value is the half maximal effective value i.e. the concentration of extract providing $50 \%$ of antioxidant activity or 0.5 absorbance. Graphs were plotted based on above data and respective $\mathrm{EC}_{50}$ values were determined from them.

\section{Statistical analysis}

Data were expressed as mean \pm S.D. (Standard deviation). Means of triplicate analyses were calculated. The Student's t test was used for comparison between standard and the sample. A difference was considered to be statistically significant when $\mathrm{p}<0.05$.

\section{RESULTS AND DISCUSSION}

The extractive yield of the ethanolic extract of $T$. clypeatus was $7 \%$. It was seen to have a good number of phytochemicals, each of which was responsible to give it a good antioxidative property. Phenolic compounds are known to be powerful chain-breaking antioxidants. Their hydroxyl groups provide them scavenging ability. In this study, the total phenolic content of the extract was noted to be $5 \pm 0.48 \mu \mathrm{g} / \mathrm{mg}$. Its estimated flavonoid content was $2.14 \pm 0.47 \mu \mathrm{g} / \mathrm{mg}$. Ascorbic acid was reported to interact directly with radicals such as $\mathrm{O}_{2}{ }^{-}$and $\mathrm{OH}$ in plasma, thus preventing damage of cells. Here, ascorbic acid content was seen to be $1.3 \pm 0.11 \mu \mathrm{g} / \mathrm{mg}$. $\beta$-carotene protects against cancer and cardiovascular diseases. Lycopene, on the other hand is one of the antioxidants that prevents carcinogenesis and atherogenesis. $\beta$-carotene and lycopene were found in very less amounts in this extract viz., $0.0014 \pm 0.0002$ and $0.0011 \pm 0.0002$ $\mu \mathrm{g} / \mathrm{mg}$ respectively.

HPLC has been done to predict phenolic composition of a fraction extracted after thermal processing. As shown in figure $1 \mathrm{a}$ and $1 \mathrm{~b}$, eleven phenolic substances were analysed and two of them were detected in the ethanolic extract of $T$. clypeatus. Our findings revealed that the dominant phenolic compounds were pyrogallol $(0.223 \mu \mathrm{g} / \mathrm{mg})$ and cinnamic acid $(0.095 \mu \mathrm{g} / \mathrm{mg})$. The response of antioxidants to different radical or oxidant sources may be different. Therefore, no single assay can be capable to reflect the mechanism of action of all radical sources or antioxidants in any system. This way, the antioxidant activity of the samples was assessed through five different methods. Superoxide anion, which is a reduced form of molecular oxygen, has been implicated in initiating oxidation reactions associated with aging (Lavhale and Mishra, 2007). With one unpaired electron, the superoxide ion is a free radical, and, like di-oxygen, it is paramagnetic. It plays an important role in formation of other reactive oxygen species, which induce oxidative damage in lipids, proteins and DNA. The extract showed superoxide radical scavenging capacity in a concentration dependant manner (Figure 2 a). The $\mathrm{EC}_{50}$ value was $0.33 \pm 0.01 \mathrm{mg} / \mathrm{ml}$. 


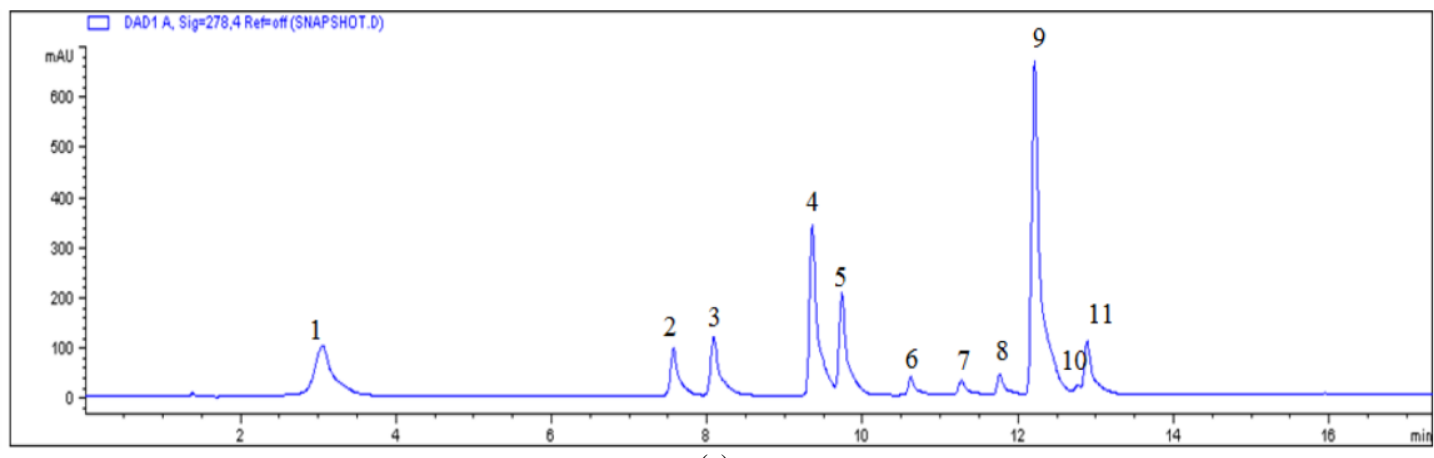

(a)

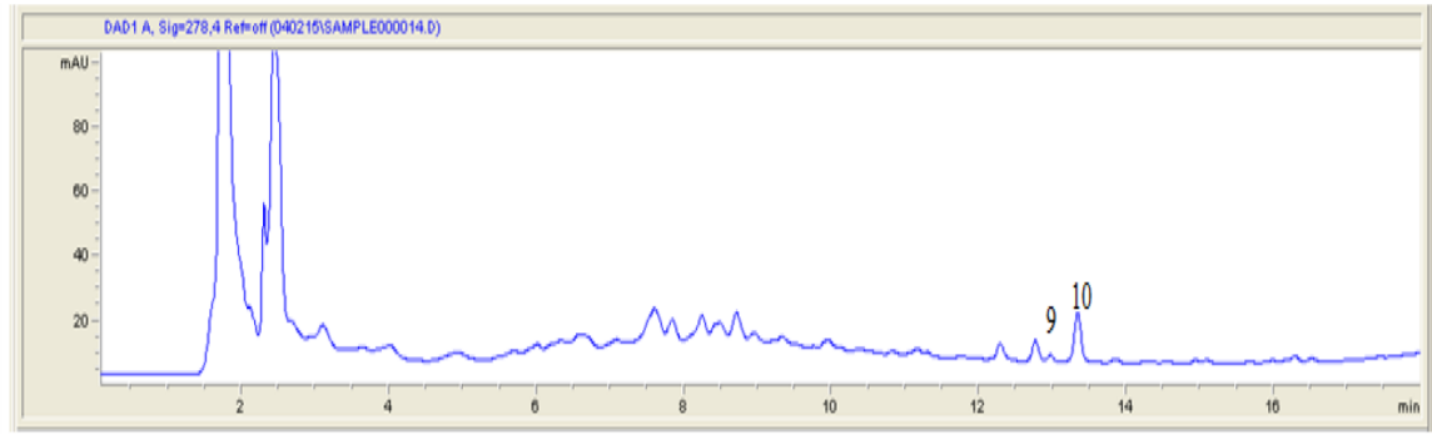

(b)

Fig. 1: HPLC chromatogram. (a) Peaks of standards: 1: gallic acid, 2: chlorogenic acid, 3: vanillic acid, 4: $p$-coumaric acid, 5: ferulic acid, 6: myricetin, 7: salicylic acid, 8: quercetin, 9: cinnamic acid, 10: pyrogallol, 11: kaempferol. (b) Peaks of ethanolic extract of Termitomyces clypeatus: (9) cinnamic acid, (10) pyrogallol.

The method is based on the auto oxidation of riboflavin in presence of light which in turn reduced NBT to form a blue colour formazan. $\mathrm{EC}_{50}$ value of it was much lower than that of ethanolic extract of Termitomyces medius $(1.40 \mathrm{mg} / \mathrm{ml})$ and Russula albonigra $(0.74 \mathrm{mg} / \mathrm{ml})$ (Mitra et al., 2014; Dasgupta et al., 2014).

The DPPH radical is a stable radical with a maximum absorbance at $517 \mathrm{~nm}$ that can readily undergo reduction by any antioxidant. The ease and convenience of this reaction has resulted in the widespread use of it in the free radical-scavenging activity assessment (Kumar et al., 2008). The DPPH radical scavenging activity of the ethanolic extract is shown in Figure $2 \mathrm{~b}$. and calculated $\mathrm{EC}_{50}$ is only at a concentration of $3.22 \pm 0.4 \mathrm{mg} / \mathrm{ml}$.

Iron generates free radical by the Fenton \& Haber-Weiss reaction. Chelation of metal ions prevents oxyradical generation and consequent oxidative damage. Chelation is an important antioxidant mechanism because it reduces concentration of the catalysing transition metal in LPO (Kumar et al., 2008). The ethanolic extract has demonstrated reasonable ferrous ion chelating efficacy (Figure 2 c.) with $\mathrm{EC}_{50}$ value at $0.21 \pm 0.03$ $\mathrm{mg} / \mathrm{ml}$, which indicated that it was a far better chelator than Termitomyces medius $(0.68 \mathrm{mg} / \mathrm{ml})$, Russula albonigra $(0.81$ $\mathrm{mg} / \mathrm{ml})$ and Amanita vaginata $(0.73 \mathrm{mg} / \mathrm{ml})$ (Mitra et al., 2014, Dasgupta et al., 2014, Paloi and Acharya, 2014). It is also reported that chelating agents that form $\sigma$-bonds with a metal, are effective as secondary antioxidants as they reduce the redox potential, thereby stabilizing the oxidised form of the metal (Srivastava et al., 2006). The reducing power assay is based on the ability of sample to reduce yellow ferric form to blue ferrous form by the action of electron-donating antioxidants (Benzie and Szeto, 1999). The extract could reduce $\mathrm{Fe}^{3+}$ to $\mathrm{Fe}^{2+}$ with $50 \%$ inhibition capacity at a concentration of $1.77 \pm 0.035 \mathrm{mg} / \mathrm{ml}$ (Figure $2 \mathrm{~d}$.). In comparison to this the $\mathrm{EC}_{50}$ value of ethanolic extract of Termitomyces medius was much higher i.e. $2.05 \mathrm{mg} / \mathrm{ml}$ (Mitra et al., 2014 a). Reductones work by breaking the chain of free radicals by donating hydrogen atoms (Mitra et al., 2014 b). This change can be monitored at 700nm, by measuring the intensity of the Perl's Prussian blue colour. In the designed experiments the extract's reducing power was compared to that of BHA, a synthetic antioxidant.

Total antioxidant capacity on the other hand was measured by the formation of green phosphomolybdenum complex. The ethanolic extract resulted in the reduction of Mo (VI) to Mo (V) and form a green phosphate/Mo (V) complex. The colour intensity was determined with the maximal absorption at $695 \mathrm{~nm}$. Ascorbic acid was used as standard. Total antioxidant capacity measured had shown that $1 \mathrm{mg}$ of extract was as functional as $1.3 \pm 0.39 \mu \mathrm{g}$ of ascorbic acid (expressed as $100 \mu \mathrm{g}$ AAE).

There were statistically significant differences between the ethanolic extract of $T$. clypeatus and the respective standards ( $\mathrm{p}$ $<0.05$ ). 


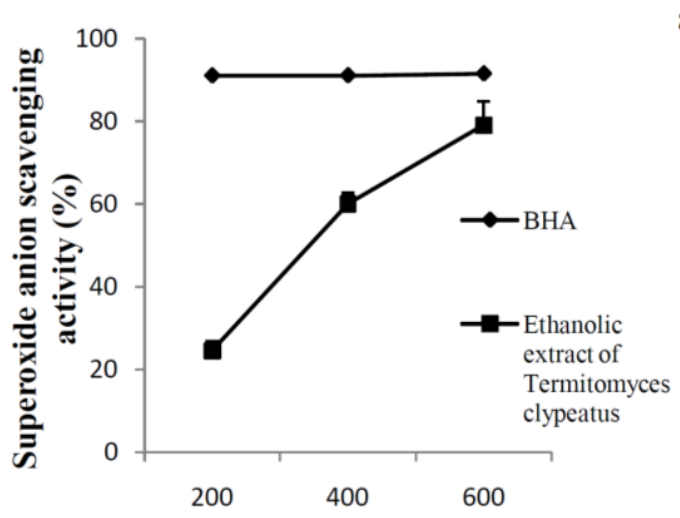

Concentration $(\mu \mathrm{g} / \mathrm{ml})$

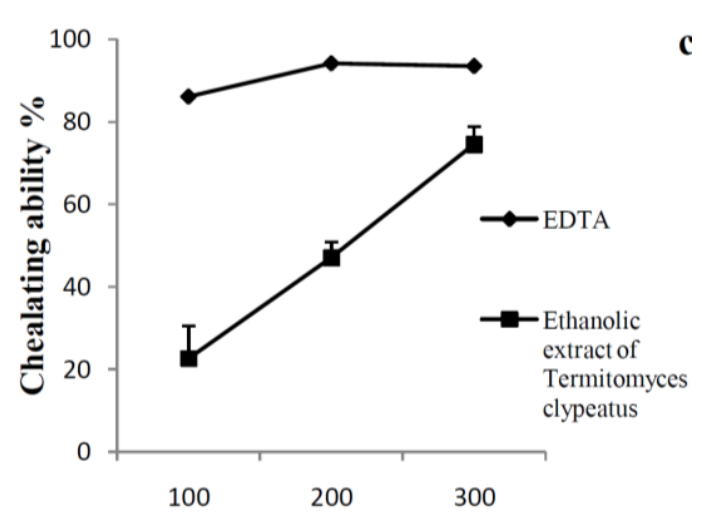

Concentration $(\mu \mathrm{g} / \mathrm{ml})$

a

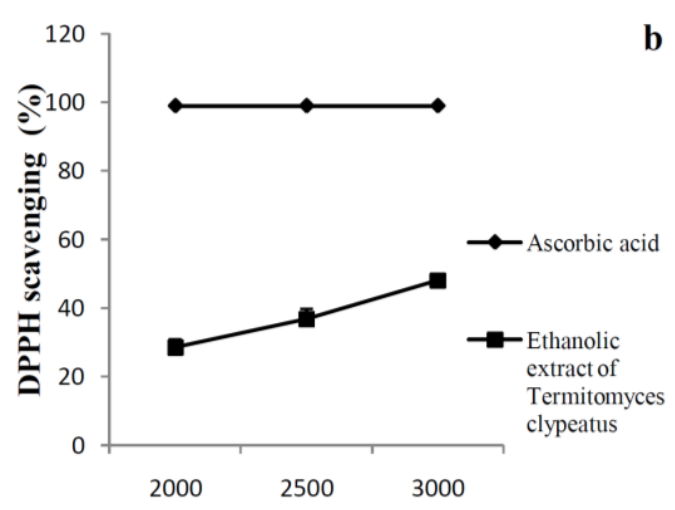

Concentration $(\mu \mathrm{g} / \mathrm{ml})$

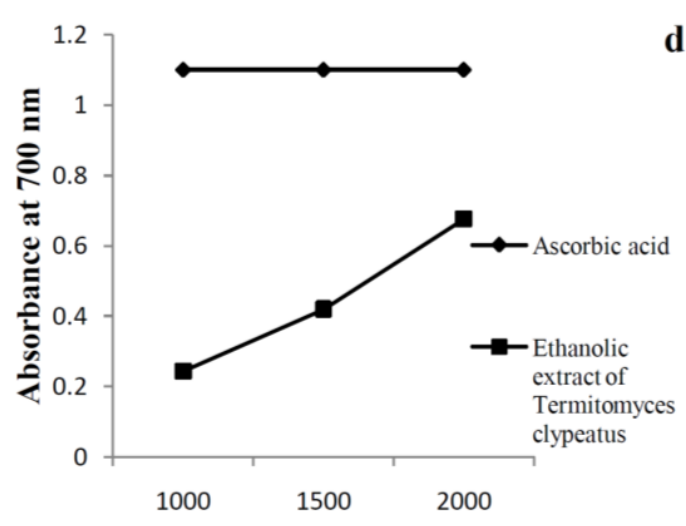

Concentration $(\mu \mathrm{g} / \mathrm{ml})$

Fig. 2: Antioxidative activities of ethanolic fraction of Termitomyces clypeatus: (a) Superoxide radical scavenging activity (b) DPPH radical scavenging activity (c) Ferrous ion chelating ability and (d) Reducing power. Results are the mean $\pm S D$ of three separate experiments, each in triplicate.

\section{CONCLUSION}

Overall, it has been verified that wild ethanolic extract of edible mushroom $T$. clypeatus has a variety of phytochemicals such as phenols, ascorbic acid, flavonoids, $\beta$ carotene and lycopene which contribute to the good antioxidant mechanisms viz., superoxide, DPPH radical scavenging activity, chelation of ferrous ion activity and reducing ability. Therefore, food modification through the balanced consumption of this mushroom is more effective and important than other nutritional supplements for the primary prevention of acute diseases.

\section{ACKNOWLEDGEMENT}

The author PM is grateful and acknowledges Innovation in Science Pursuit for Inspired Research of Department of Science $\&$ Technology for financial support.

\section{REFERENCES}

Ames BN, Shigenaga MK, Hagen TM. Oxidants, antioxidants, and the degenerative diseases of aging. Proc Natl Acad Sci USA, 1993; 90:7915-22.

Benzie IFF, Szeto YT Total antioxidant capacity of teas by the ferric reducing/antioxidant power (FRAP) assay. J Agric Food Chem, $1999 ; 47: 633-36$
Biswas G, Acharya K. Hypoglycemic activity of ethanolic extract of Astraeus hygrometricus (Pers.) Morg. in alloxaninduced diabetic mice. Int J Pharm Pharm Sci, 2013; 5:391-94.

Biswas G, Rana S, Sarkar S, Acharya K. Cardioprotective activity of ethanolic extract of Astraeus hygrometricus (Pers.) Morg. Pharmacologyonline, 2011; 2:808-17.

Biswas G, Sarkar S, Acharya K. Free radical scavenging and anti-inflammatory activities of the extracts of Astraeus hygrometricus (Pers.) Morg. Lat Am J Pharm, 2010; 29:549-53.

Chatterjee A, Acharya K. Include mushroom in daily diet-A strategy for better hepatic health. Food Res Int, 2016; 32:68-97.

Chatterjee A, Khatua S, Chatterjee S, Mukherjee S, Mukherjee A, Paloi S et al. Polysaccharide-rich fraction of Termitomyces eurhizus accelerate healing of indo methacin induced gastric ulcer in mice. Glycoconj J, 2013; 30:759-68.

Chatterjee S, Biswas G, Chandra S, Saha GK, Acharya K. Chemo preventive effect of Tricholoma giganteum against benzo[a]pyrene-induced forestomach cancer in Swiss albino mice. Int J Pharm Sci Rev Res. 2014; 26: 189-96.

Dasgupta A, Rai M, Acharya K, Chemical Composition and Antioxidant Activity of a wild Edible Mushroom Pleurotous flabellatus. Int J PharmTech Res, 2013; 5:1655-63.

Dasgupta A, Ray D, Chatterjee A, Roy A, Acharya K. In vitro antioxidative behaviour of ethanolic extract of Russula albonigra. J Chem Pharm Res, 2014; 6:1366-72.

Dinis TCP, Madeira VMC, Almeida LM. Action of phenolic derivates (acetoaminophen, salycilate, and 5-aminosalycilate) as inhibitors of membrane lipid peroxidation and as peroxyl radical scavengers. Arch Biochem Biophys, 1994; 315:161-9. 
Fraga CG, Shigenaga MK, Park JW, Degant P, Ames BN. Oxidative damage to DNA during aging: 8-Hydroxy-2'-deoxyguanosine in rat organ DNA and urine. Proc Natl Acad Sci USA, 1990; 87:4533-7. 78:7124-8

Harman D. The aging process. Proc Natl Acad Sci USA, 1981;

Karun NC, Sridhar KR. Occurrence and distribution of Termitomyces (Basidiomycota, Agaricales) in the Western Ghats and on the west coast of India. Czech Mycology, 2013; 65:233-54.

Khatua S, Paul S, Acharya K. Mushroom as the potential source of new generation of antioxidant: A review. Res J Pharm Tech, 2013; 6:496-505.

Kumar KS, Ganesan K, Subha Rao PV. Antioxidant potential of solvent extract of Kappaphyus alvarezii (Doty) Doty- An edible seaweed. Food Chem, 2008; 107: 289-95.

Lavhate MS, Mishra SH. Evaluation of free radical scavenging activity of Butea monosperma Lam. Indian J Exp Biol, 2007; 45:376-84.

Mallick S, Dutta A, Dey S, Ghosh J, Mukherjee D, Sultana SS et al. Selective inhibition of Leishmania donovani by active extracts of wild mushrooms used by the tribal population of India: An in vitro exploration for new leads against parasitic protozoans. Exp Parasitol, 2014; 138:9-17.

Mallick S, Dey S, Mandal S, Dutta A, Mukherjee D, Biswas G et al. A novel triterpene from Astraeus hygrometricus induces reactive oxygen species leading to death in Leishmania donovani. Future Microbiol, 2015; 10:763-89.

Martinez AC, Marcelo EL, Marco AO, Moacyr M. Differential responses of superoxide dismutase in freezing resistant Solanum curtibolum and freezing sensitive Solanum tuberosum subjected to oxidative and water stress. Plant Science, 2001; 160:505-15.

Mitra P, Mandal NC, Acharya K. Phytochemical characteristics and free radical scavenging activity of ethanolic extract of Termitomyces microcarpus R. Heim. Der Pharmacia Lettre, 2014; 6:92-8.

Mitra P, Sarkar J, Mandal NC, Acharya K. Phytochemical analysis and evaluation of antioxidant efficacy of ethanolic extract of Termitomyces medius. Int J Pharm Sci Rev Res, 2014; 27:261-6.

Nagata M, Yamashita I. Simple method for simultaneous determination of chlorophyll and carotenoids in tomato fruit. J Jpn Soc Food Sci, 1992; 39:925-8.

Oyaizu M. Studies on product of browning reaction prepared from glucose amine. Jpn J Nutr, 1986; 44:307-15.

Paloi S, Acharya K. Evaluation of antioxidative activity and chemical composition of ethanolic extract from Amanita vaginata (Bull.) Lam.: an in vitro study. Asian J Pharm Clin Res, 2014; 7:88-92.
Park YK, Koo MH, Ikegaki M, Contado JL. Comparison of the flavonoid aglycone contents of Apis mellifera propolis from various regions of Brazil. Arquivos De Biologia E Tecnologia, 1997; 40:97-106.

Pattanayak M, Samanta S, Maity P, Sen IK, Nandi AK, Manna DK et al. Heteroglycan of an edible mushroom T. clypeatus: structure elucidation and antioxidant properties. Carbohydr Res, 2015; 413:30-6.

Prieto P, Pineda M, Aguilar M. Spectrophotometric quantitation of antioxidant capacity through the formation of a phosphor molybdenum complex: specific application to the determination of vitamin. Anal Biochem, 1999; 269:337-41.

Rai M, Sen S, Acharya K, Antimicrobial activity of four wild edible mushrooms from Darjeeling hills, West Bengal, India. Int J PharmTech Res, 2013; 5:949-56.

Rekha C, Poornima G, Manasa M, Abhipsa V, Pavithra DJ, Vijay KHT, Prashith KTR. Ascorbic Acid, Total Phenol Content and Antioxidant Activity of Fresh Juices of Four Ripe and Unripe Citrus Fruits. Chem Sci Trans, 2012; 1:303-10.

Shimada K, Fujikaw K, Yahara K, Nakamura T. Antioxidative properties of xanthan on the autoxidation of soyabean oil in cyclodextrin emulsion. J Agr Food Chem, 1992; 40:945-48.

Sies H. Biochemistry of oxidative stress. Angew Chem Int Ed Engl, 1986; 25:1058-71.

Singleton VL, Rossi JA. Colorimetry of total phenolics with Phosphomolybdic-Phosphotungstic Acid Reagents. Am J Enol Vitic, $1965 ; 16: 144-58$.

Srivastava A, Harish SR, Shivanandappa T. Antioxidant activity of the roots of Decalepis hamiltonii (Wight \& Arn). LWT, 2006; 39:105965 .

Wagner JR, Hu CC, Ames BN. Endogeneous oxidative damage of deoxycytidine in DNA. Proc Natl Acad Sci USA, 1992; 89:3380-4.

\section{How to cite this article:}

Mitra P, Mandal NC, Roy A, Acharya K. Phytochemical Study and Antioxidative Property of Ethanolic Extract from Termitomyces clypeatus. J App Pharm Sci, 2016; 6 (07): 120-124. 